\title{
Angeliki Kordoni, La Littérature dans les Départements de Langue et de Littérature françaises en Grèce : enjeux, représentations, méthodes, propositions didactiques.
}

Thèse de doctorat en Didactique des langues et des cultures sous la direction de Emmanuel Fraisse (Université Sorbonne Nouvelle - Paris 3), soutenue à l'Université Sorbonne Nouvelle-Paris 3, le 10 avril 2014 (369 pages \& annexes 284 pages).

\section{Angeliki Kordoni}

\section{(2) OpenEdition Journals}

Édition électronique

URL : https://journals.openedition.org/dhfles/4445

DOI : $10.4000 /$ dhfles.4445

ISSN : 2221-4038

Éditeur

Société Internationale pour l'Histoire du Français Langue Étrangère ou Seconde

Édition imprimée

Date de publication : 1 décembre 2017

Pagination : 202-208

ISSN : 0992-7654

Référence électronique

Angeliki Kordoni, «Angeliki Kordoni, La Littérature dans les Départements de Langue et de Littérature françaises en Grèce : enjeux, représentations, méthodes, propositions didactiques. », Documents pour I'histoire du français langue étrangère ou seconde [En ligne], 58-59 | 2017, mis en ligne le 02 mai 2018, consulté le 30 mars 2023. URL : http://journals.openedition.org/dhfles/4445 ; DOl : https://doi.org/ $10.4000 /$ dhfles. 4445

Ce document a été généré automatiquement le 30 mars 2023.

Tous droits réservés 
